\title{
THE RENTS OF THE DEAD: GROWTH AND ENTROPY IN AFRICAN CITIES
}

\begin{abstract}
James R. Brennan
Department of History, University of Illinois at Urbana-Champaign, USA

This article considers recent literature on contemporary urbanization in Africa that is united in its 'post-normative' orientation toward its subject, firmly discarding the 'expectations' of modernization that so deeply shaped twentieth-century research on African cities. Best typified by the work of urban anthropologists such as Abdoumaliq Simone, this scholarship instead focuses on the 'vernacularization' of urban structures and strategies in Africa. While such work has developed a host of new insights into the idiosyncratic nature of African urbanization, it has largely eschewed any comparative analysis of enduring economic strategies that lie at the heart of the massive growth of African cities. By focusing on the longer-term historical role of such processes - namely urban rents and urban price regulations - this article suggests that a more comparative framework can be generated for the study of urban Africa that still accounts for and partially explains the otherwise seemingly hyper-local and idiosyncratic forms of urban livelihoods and strategies. It also briefly reflects on notable trends in the five years since its original publication in 2013
\end{abstract}

KEYWORDS: URBAN HISTORY, URBANIZATION, CONSUMPTION, RENT, PRICE CONTROLS

\section{Prologue}

Looking back five years since the publication of this article, two things seem most relevant. ${ }^{\mathrm{I}}$ First, the continued rise in centrally-located urban land values, driven by varying combinations of demand and speculative investment, has locked in an architectural form skyscraper urbanism across several dozen African cities. This commercial fortification more sharply divides 'urban' from 'peri-urban' landscapes, which had been previously articulated in a much more gradualist manner. Second, the social resilience of the African necropolis in close proximity to such transformed urban spaces, typically taking the form of Christian and Muslim cemeteries, marks a rich site of social and economic contestation over local community claims to ownership and memory in the face of capital-intensive and often speculation-driven urban transformation, and mark some of continent's most highly-pressurized transition zones between the urban and peri-urban. In Dar es Salaam, Muslim cemeteries in particular, owned by various forms of community - such as a single family (Tambaza in Upanga), an ethnic community (Manyema in Ilala), and the wider Sunni umma (the Muslim cemetery in Kisutu) - has created diverse forms of community mobilization to protect urban land holdings, which have all come under speculative ga- 
zes over the past decade because of their superior central locations. Rent-seeking urban landlords, who in a city such as Dar es Salaam have historically played the leading role in urban property development, will increasingly need to mediate historical community claims, grounded most powerfully in the urban necropolis, with the opportunities and demands of large-scale investors for multi-storied building sites, in order to retain their economic and social position in the African cities of the near future.

\section{Introduction}

Where are we today in the study of African cities? The normative 'dualist' view - that African cities represent a separate realm of 'modern' urban life surrounded by 'traditional' countryside - long stood at the center of colonial urban ethnography, and proved remarkably persistent in the decades that followed colonial rule. But its grip did eventually slacken and give way to what might be termed a 'post-normative' view of African cities, in which urbanization is something other than what its planners, leaders, or theorists had intended it to be. This post-normative approach defined the most vital work in the field, such as James Ferguson's Expectations of Modernity, which memorably criticizes the evolutionary view of urbanization, and turns our attention to the role of style, how urban individuals adopt elements of either 'localist' or 'cosmopolitan' styles even amid the failure of the urban economy to deliver on its promises. ${ }^{2}$ Several elements of Ferguson's picture, built from his late-I980 fieldwork, however already seem curiously dated. Global copper prices took off in 2004 and have largely remained at decades-level highs ever since. This, combined with enormous Chinese investment in Zambia's mines, have together created new orientations around what it means to be 'cosmopolitan', as well as creating novel forms of oppositionist and xenophobic politics. In short, Zambia's copperbelt cannot simply stand either as a straightforward example of evolutionary urbanization, or as an exhibit of post-modern and post-industrial 'disconnect', as it had during the booming I960s and moribund I99os, respectively. Whether or not Africa's much-vaunted 'cheetahs' of the 2000 s will continue to match optimists' expectations of interconnected economic growth and improved governance over the coming years as they have over the past decade ${ }^{3}$, there is little question that urban centers will be a moving target for urban analysts, who will seek to keep pace through the rapid and experimental adoption of new methodological and theoretical frameworks.

If the spirit of Ferguson's copperbelt is marked by regional nostalgia and global disconnection, much of the current post-normative literature on urban Africa focuses instead on an impossibly open-ended present and future of deeply diverse locales. This is particularly pronounced in ethnographic research of what Jane Guyer has recently termed 'Describing Urban "No Man's Land” in Africa', in which cities are characterized as 'elu-

2 James Ferguson, Expectations of Modernity: Myths and Meanings of Urban Life on the Zambian Copperbelt (Berkeley: University of California Press, 1999).

3 The most rigorous account of this view is Steven Radelet, Emerging Africa: how 17 countries are leading the way (Washington DC: Center for Global Development, 2010). 
sive, invisible, yet to come'. ${ }^{4}$ Her characterization of the research, from which these three terms originate - the books of Sarah Nuttall and Achille Mbembe, Filip de Boeck and Marie-Francoise Plissart, and Abdoumaliq Simone, respectively - can be summarized thusly: '[i]n the ether of the invisible, what circulates are symbols and expressions; what emanates from bodies is sexual tension, aesthetic sensibility and physical vulnerability ... what bears down oppressively is constraint and neglect of all kinds. In brief, what strikes the perceptive mind is precisely what burst out of the conventional forms and has not yet taken a newly conventionalized shape'. ${ }^{5}$ This is emphatically not a story of long temporal swings in global markets and transnational ideologies. It is instead an approach marked by intimate empathy, and the ethnographer's subject is often ephemerality, disjuncture, and possibility. Such ethnographic realism is not, as Guyer argues, 'in the service of systemics (as in modernism), nor of extricating divergent contending discourses (as in post-modernism) but is crafted better to "grasp the native's point of view", and to document the "imponderability of actual life" within incongruence'. The message of this approach is that older, more conventional methods of ethnography - and by extension, methods of social science, history, linguistics, et cetera - cannot cope with the incongruity, because they cannot anticipate the heterogeneity and unconventional nature of African cities, both past and present. These are important insights. For Guyer's part, she highlights, and indeed endorses, the eclectic, episodic, ethereal, and idiosyncratic method of these authors, who use a format that 'privileges the impression and the impressiveness of things, as experienced by different participants, in different places, from different angles and with different interests'. ${ }^{6}$

But such approaches also reveal limitations. Simone's For the City Yet to Come, for example, begins with a brief but reliable guide to the general retreat of formal state participation in African cities since the I970s, but in its wake posits no continent-wide generalizations but rather four distinct 'notions'. These 'notions' constitute 'provisional, highly fluid, yet coordinated and collective actions', which arise alongside the proliferation of 'decentralized local authorities, small-scale enterprises, community associations, and civil society organizations'. ${ }^{7}$ These 'notions' are also Simone's descriptors of the four cities of Dakar, Pretoria, Douala, and Jidda - or 'The Informal', 'The Invisible', 'The Spectral', and 'Movement'. Their purpose is to convey how processes of urban operation in contemporary Africa work, and are meant to serve 'as ways of bringing the city into some kind of focus and for leveraging access to the effects of urban forces and practices otherwise not easy to apprehend', as an alternative to 'the concentration on analytical languages that attempt to account for urban life through a specific delineation of social identities, sectors, and

$4 \quad$ Jane I. Guyer, 'Describing Urban 'No Man's Land' in Africa', Africa 83 (2011), 474-92.

5 Guyer, 475. The works are Sarah Nuttall and Achille Mbembe (eds.), Johannesburg: the elusive metropolis (Johannesburg and Durham NC: Witwatersrand University Press and Duke University Press, 2008); Filip de Boeck and Marie-Françoise Plissart, Kinshasa: tales of the invisible city (Tervuren and Ludion: Royam Museum of Central Africa and Vlaams Architectuureninstituut Vai, 2004); and Abdoumaliq Simone, For the City Yet to Come: changing African life in four cities (Durham NC: Duke University Press, 2004).

6 Guyer, 484.

7 Simone, For the City Yet to Come, I3. 
institutions. ${ }^{8}$ This is an appealing approach, seeking to divine emic categories of urbanization rather than imposing etic ones. But this is also wholly interpretive and seemingly impervious to deployment for comparative purpose, particularly when Simone's core message is the capacity of African cities 'to generate new and largely ephemeral forms of social collaboration' ${ }^{9}$

My point here is not at all to abandon locally specific urban ethnography in preference for a comparative, typology-bound approach to African urban studies. The work of Anthony O'Conner is excellent, but the effect of six African city types - 'indigenous', 'Islamic', 'colonial', 'European', 'dual', and 'hybrid'เo - has been to turn our focus onto what fits and does not fit, rather than to illuminate important comparative and contrastive trends in forms of African urbanization. Moreover, typologies based on space or function implicitly reflect the biases of the urban planner. The story of Africa's urbanization, particularly over the past few decades, is the comparative impotence or even irrelevance of urban planning, and the emergence of unanticipated heterogeneity. Richard Grant summarizes what might be fairly termed the operating academic consensus on how best to understand Africa's urban environment - as 'truncated modernization: the evolving city is fragmented, chaotic, and spatially messy'. ${ }^{\text {II }}$ Yet dissolving or otherwise transcending the old dualism of 'tradition' versus 'modernity' and embracing heterogeneity is not enough. We should turn our attention especially to comparative elements of economic strategy in Africa's urban past and present, which include the host of idiosyncratic urban modes of livelihood and unexpected forms of associational life so well mapped out by Simone and others. Simone's plea that we understand urbanization in Africa as a type of vernacularization, in which a form of shared spatial subaltern language, or 'spectral urbanism', is characterized by creative reconnections of resources, objects and bodies de-territorialized from earlier signifying regimes, is a vital one. ${ }^{12}$ This also raises important questions about the formation of political power in such inchoate and unpredictable spaces. Laurent Fourchard has urged historians of African cities to analyze 'the multiple, ambivalent, and non-linear city/state relationships on the continent' as a way of moving beyond normative visions of the state, while 'facilitating the interrogation of this relatively unexplored issue in the analysis of state formation in Africa' ${ }^{13}$ Posing conventional questions of economic and political comparison within an acknowledged post-normative light that accepts wildly heterogeneous forms of African urban life can yield much analytical and interpretive profit.

8 Ibid., I3-I4.

9 Ibid., 2 I4.

Io Anthony O'Connor, The African City (New York: Africana Publishing Company, I983), 9-I2.

II Richard Grant, Globalizing City: The Urban and Economic Transformation of Accra, Ghana (Syracuse: Syracuse University Press, 2009), 7.

I2 Simone, For the City Yet to Come, especially 92-II7.

I3 Laurent Fourchard, 'Between World History and State Formation: New Perspectives on Africa's Cities', Journal of African History 52 (201I), 227. 
Furthermore, post-normative frameworks could also benefit from the earnest quest for social justice that animates the work of urban geographers such as Garth Myers, who argues that ' $[t]$ he challenges for African urban studies no longer lie simply or solely with paying more theoretical attention to the marginalized informal, invisible, spectral, necropolitan or ordinary settings across the cities of the continent - important as this may be'. Myers instead argues for a useable, activist scholarship that lies 'equally in practice, in then attempting to articulate how such urbanization processes might contribute to efforts to improve the quality of life for the inhabitants of these places' ${ }^{\text {I4 }}$ All cities in this view are both global and the product of local politics. So it is in this appreciative but critical understanding of the post-normative spirit of contemporary African urban studies that I offer a somewhat different focus, one that is more material than ethereal, where prices matter as much as values. After an overview of the role played by 'demand' in African urbanization, this article examines in more detail the role of income strategies (rents) and spatial benefits (entitlements) that others have identified, and that I found particularly crucial in the case of Dar es Salaam, Tanzania. In this, one can see the improvisations of urban actors working within less visible but no less enduring (and certainly non-ephemeral) economic structures of African urban life.

\section{Demands for the city}

A lingering sense of abstemious virtue has seemed to inform both the academic and public imagination that cities were inherently unproductive places, and that Africans were ill-served by pursuing urban lives in which luxury and consumption formed a significant part of the economic landscape. The haunting juxtaposition of enormous wealth alongside dire poverty often tends to entrench this view across the political spectrum, firming the convictions of colonial-era administrators, rural African gerontocrats, development enthusiasts, and anti-capitalist leftists alike, that cities are sites of impoverishment and immiseration. The most prominent recent case of this latter group is Mike Davis' account, Planet of Slums, which connects an utterly dystopian view of 'Third World' urbanization with a stinging condemnation of neo-liberal policies. Davis certainly does not advocate a return to rural bliss, but his ceaseless and rather lurid emphasis on all that is squalid, diseased, and wretched about slum life raises some rather basic questions about the relationship between urbanization and poverty. ${ }^{15}$ Such a portrait requires sharpening and correction, both through entertaining ideological challenge and pursuing greater analytical rigor. Davis portrays the swelling of 'Third World' slums as an inescapable penitentiary for the urban-bound poor. Yet the presence of poverty in cities across the globe might alternatively be said to reflect urban strength as much as urban weakness. As the libertarian-minded urban economist Edward Glaeser has argued, '[c]ities aren't full of poor people because cities make people poor, but because cities attract poor people with 
the prospect of improving their lot in life' ${ }^{16}$ People flock to African cities in general not out of coercion - unless coercion is defined so broadly as to lose any precision to account for a spatial component - or out of madness or mistaken beliefs. They flock to urban areas, Glaeser explains, 'because cities offer advantages they couldn't find in their previous homes'. The deep wish that people remain in agricultural isolation has been shared by a politically motley bunch - colonial officials, anti-colonial liberationist figures such as Julius Nyerere, and contemporary preservationists across large swathes of the West today. Glaeser concludes that, by offering far more possibilities in connecting capital-less workers with capital-rich employers, 'cities, not farms, will save the developing world'. ${ }^{17}$ Yet Glaeser's own Pollyanish views on 'Third World' urbanism might also be effectively challenged on Glaeser's own ground of economics. A recent study by the World Bank, for example, surprisingly demonstrates some African countries to be the exception to the larger global trend that shows a positive correlation between the movement of people to cities and the growth in wealth. This study instead shows that in a number of sub-Saharan African cases, there is either a negative correlation (Liberia, Zimbabwe) or basically neutral correlation (Cameroon, Nigeria, Kenya) between urbanization and GDP growth, perhaps because micro-entrepreneurial work carries with it such low earnings and does not necessarily lead to net job creation and productivity growth. ${ }^{18}$ Furthermore, libertarian optimism might seem wide of the mark when set aside the recent work of Deborah Potts, who argues that Africa is currently undergoing a parallel 'de-urbanization' that accompanies, and in some areas outpaces, the wider trend of urbanization. According to aggregate United Nations data, Africa's urbanization in whole - whether to first-order or second-order cities - continues to grow, and is not reversing. But Potts raises important questions by offering analytical distinctions among the population of urban-dwellers that must be considered when generalizing about 'urbanization'. She argues that there are four groups of people in cities today, 'willing stayers, reluctant stayers, willing leavers, and reluctant leavers'. When urban living standards decline severely, there is an under-studied push and movement of peoples back to rural areas. Potts concludes that 'often mobility has remained high, or even increased, but the net movement into large towns has decreased as circulation has increased'. ${ }^{19}$ Whether or not African cities can be generalized as primarily sites of superior economic realization or impoverishment, the reasons why individuals and groups choose to move to, to stay in, and to leave cities remain vital. Thus, an earlier scholarly generation's concerns with the causes of urbanization, though undoubtedly overshadowed by a subsequent generation's concerns with urbanization's effects, should draw our attention to the question of realizing desire within a spatial framework.

I6 Edward Glaeser, Triumph of the City: How Our Greatest Invention Makes Us Richer, Smarter, Greener, Healthier, and Happier (New York: Penguin, 20II), 70.

I7 Glaeser, 75 .

I8 World Development 2013: Jobs (Washington DC: World Bank, 2012), 52-54.

I9 Deborah Potts, 'Making a Livelihood in (and Beyond) the African City: The Experience of Zimbabwe', Africa 8I (4) $2011: 602$. 
My book, Taifa: Making Nation and Race in Urban Tanzania, argues that the city is best understood primarily as a site of consumption. ${ }^{20}$ Labor loomed large as a worry for colonial administrators, but their first worry was to secure urban control through regulating the price and access to basic consumer needs - food, clothing, and housing - to manage the population of Dar es Salaam, which swelled during the I940s. State management of urban consumer goods became the platform upon which the city's racial politics - that pitted African and Indian claims on the city against one another - grew to form the basis of nationalist politics. People came to cities such as Dar es Salaam not only to make money but also to generate social capital, which in turn opened up new possibilities for the creation of political power. It was in Dar es Salaam where the Tanganyika African National Union (TANU) was not only formed in 1954, but came to politically dominate the city in I955, providing a platform for territory-wide political domination over the next few years that would lead directly to independence in i96r. Urban space thus provided propitious postwar political connections that were wholly unintended by either European administrators or African immigrants.

This unintended nature of cities, which results from the uncoordinated desires and demands of individuals, furnishes its most vital and exciting characteristics. Yet these characteristics might not be quite as ephemeral or locally unique as observers like Simone suggest. The urban pursuit of desire has created a host of mixed 'externalities', the impact that a person's actions have on another person that does not come about through a voluntary transaction. This includes both positive externalities that attracts people to cities, such as the economic opportunities for comparatively high wages and enormous opportunities in the realms of education and culture, as well as negative externalities such as general urban pollution, dire sanitation, high rents (as viewed by renters), and endless traffic, which together has formed the trade-offs that individuals weighed when deciding to whether to come, stay, or leave. Such externalities, economists point out, have never been effectively 'priced' to more efficiently manage the costs and benefits of these externalities, perhaps most noticeably today in the continent's rapidly spiraling difficulties with urban traffic congestion. As Glaeser argues, when people drive, they do not 'usually consider the costs - the lost time - we impose on every other driver. We don't consider the congestion we create, and as a result, we overuse the highways' ${ }^{21}$ Congestion charges seem a considerable distance in the future as a practical way for African governments manage the hopelessly congested roads of Dar es Salaam, Lagos, Kinshasa, et cetera, particularly as the enormous power of institutional interests - be it the imported automobile sales businesses in Dar es Salaam, or the Nigeria Truck Owners Association lobby in Lagos - have far more incentive and muscle to maintain the status quo than do the overlapping, confused, and underfunded state authorities formally charged with maintaining a workable urban roads network. ${ }^{22}$ In short, students of African cities

James R. Brennan, Taifa: Making Nation and Race in Urban Tanzania (Athens: Ohio University Press, 20I2), particularly chapter 3 .

Glaeser, I58.

On Nigeria, see Joshua Hammer, 'World's Worst Traffic Jam: How a 40-mile trip to Lagos took I2 hours', The 
should consider taking up, if not the terminology of economics, at least its spirit - here, consideration of the vital roles played by tradeoffs and externalities - when generalizing about the decisions and strategies of actors, and the creation of new structures that both empower and limit the realization of actors' desires.

\section{Rents and entitlements}

The Marxist heritage is particularly strong in studies of African urban history. Colonial African cities in particular have often been cast broadly in terms of material conflict between colonial states and their unruly African subjects. ${ }^{23}$ At its best - such as in the studies of Mombasa carried out by Frederick Cooper - the subtle questions of coercion and resistance are located in the struggle over production itself, and how such struggles are at the center of debates over wages, terms of urban work, and larger questions of citizenship and belonging in colonial cities. ${ }^{24}$ More recent works that take up the spirit of Marxist protest to investigate urban immiseration - again, Mike Davis' Planet of Slums stands out because of its visibility - have taken the international economy and international capitalist institutions such as the International Monetary Fund to task. Such authors have in turn lost some of the rigor that typified earlier Marxist studies, which had earlier posed sweeping questions to be answered by specific methodological prescriptions - namely by examining closely how production actually works, with enormous comparative utility. Yet more recent authors readily acknowledge the central role of rents and 'landlordism' in the formation of urban space, something which the previous generation of Marxists had often tended to ignore or minimize. Mike Davis, for example, correctly stresses the significance of landlordism, describing it as 'the principle way in which urban poor people can monetize their equity (formal or informal),' but then quickly moralizes an analytical retreat by concluding that they do so 'often in an exploitative relationship to even poorer people'. ${ }^{25}$ His Planet of Slums is a tale driven by its villains - Nairobi's slums are portrayed as 'vast rent plantations owned by politicians and the upper middle class ${ }^{\prime 26}$, even though Davis' main source for this generalization carefully cautions that 'while some of these landlords are well-off, it would be a mistake to underestimate the number of the urban poor who depend solely on this sector for a livelihood'. ${ }^{27}$ Martin Murray employs similarly dualistic and dramatic terminologies

Atlantic, July/August 2012.

23 For a good reminder of the strengths of this approach, see Bill Freund, The African City: A History (Cambridge: Cambridge University Press, 2007).

Frederick Cooper, From Slaves to Squatters: Plantation Labor and Agriculture in Zanzibar and Coastal Kenya, 1890-1925 (New Haven: Yale University Press, I980); and idem., On the African Waterfront: Urban Disorder and the Transformation of Work in Colonial Mombasa (New Haven: Yale University Press, 1987).

Mike Davis, Planet of Slums (London: Verso, 2006), 42.

26 Davis, 87. For a similarly dualistic view of Nairobi's most renown 'slum' of Kibera, see Robert Neuwirth, Shadow Cities: A Billion Squatters, a New Urban World (London: Routledge, 2005), 67-99. For an important corrective that takes seriously the role of patronage, economic differentiation and ethnicity among Kibera landlords and tenants, see Johan de Smedt, 'No Raila, No Peace! Big Man Politics and Election Violence at the Kibera Grassroots', African Affairs 108 (2009), 58I-598. 
of the powerful and the oppressed to portray post-apartheid Johannesburg, a city where the critical rent-seeking actors are '[u]nscrupulous slumlords' who 'took advantage of the pent-up demand for accommodation in the inner city by demanding high rents, encouraging the subdivision of residential units so as to maximize occupancy' and thereby allow 'properties to fall into an irretrievable state of disrepair'.$^{28}$ Such dualistic visions of urban rents as primarily a process of immiseration generated by the powerful extracting from the weak, while presenting a welcome shift in focus to the rent-seeking economies that define street-level urban life, however obscure the finely grained nature of such chains of rent-seeking within and among the urban poor, as well as the range of motivations that generates such activity, the most resilient of which is the quest for economic security.

Among the more arresting features of contemporary African urbanization are its skyrocketing property values and utterly opaque urban land markets. The urban geographer Richard Grant sensibly asks, 'How is it that individuals buy property when traditional land law does not permit land sales? How can individuals pay between US\$25,000 and US $\$ 300,000$ for houses when Ghana's per capital income is around US\$400 and mortgages are scarce?' Echoing the anti-neoliberal dualism of Davis, Grant finds his answer outside of Africa, in the new 'transnationalism' of post-I9gos liberalization, which unleashed a wave of wealthy 'transmigrants' who upended Accra's real estate market by fueling the demand for expensive gated enclaves. Such a revolution stands in strong contrast to what Grant purports to be the more innocent pre-liberalization era in Accra, when homes 'served as a public good and entailed significant obligations and attachments. ${ }^{29}$ The scale of Accra's urban land market was undoubtedly more limited, yet this view, a sort of urban 'Merrie Africa' of rent-free family compound living ${ }^{3 \circ}$, ignores that urban land speculation and rent-seeking strategies were core dynamics of the African cities long before the I990s. A century earlier, in I89os Accra, local chiefs had responded to the colonial abrogation of their judicial and taxation powers by becoming urban land brokers; by the IgIos, they fiercely competed with lineage heads and private individuals 'to establish control or outright ownership over land', in turn generating 'a kaleidoscope of legal struggles'. ${ }^{31}$ Further north in colonial Kumasi, Sara Berry has demonstrated how commoners, chiefs, and colonial officials alike struggled to control the mightily profitable business of urban land allocation. Colonial formalizing of 'customary' urban land principles did little to discourage land commercialization in practice; indeed a bustling urban mortgage market had already taken root by the I930s. ${ }^{32}$ Tom McCaskie notes that suburban Kumasi's land boom which followed the Second World War created an anar-

28 Martin J. Murray, City of Extremes: The Spatial Politics of Johannesburg (Durham: Duke University Press, $201 \mathrm{I})$, I43.

29 Grant, $17,45$.

30 Simone similarly generalizes that '[i]n most of Africa, land persists in being viewed largely as a public good', though is more helpful in stressing the willful opacity that characterizes urban land transactions. Simone, For the City Yet to Come, I92 \& 207-208. John Parker, Making the Town: Ga State and Society in Early Colonial Accra (Portsmouth NH: Heinemann, 200o), I46, I98 (quotation at ig8). 
chic playing field that bedeviled urban planners and enriched rent-seeking speculators:

'The housing sector was overtaken by rental sub-lettings on a huge scale as those individuals with clear title to plots sought to optimize their returns. Indeed, rental payments from tenants to landlords living in the same dwelling swiftly became a major source of revenue in Ayigya's booming building economy.'

Traditional forms of tenure for urban homes in Ghana, therefore, were hardly expressions of an anti-capitalist ethos that would secure the 'public good' of universal, family-compound based housing, but rather proved remarkably adaptable to fierce commercial competition over increasingly scarce and valuable land. Token payments to traditional authorities, such as customary 'drink money' paid to the Asantehene to secure urban plot titles, were now reassessed to reflect going market rates. ${ }^{33}$ Such chiefly rentseeking underscores Berry's larger insight that property, both in Asante and more generally in sub-Saharan Africa, is better understood as a social process rather than a set of initial conditions. ${ }^{34}$ These social processes involve the mobilization of local histories and secret knowledge to navigate competing and overlapping authorities. Within these social processes, opacity in urban land ownership serves as an effective and resilient tool for seeking and negotiating rents, constantly reproducing the very conditions bemoaned by transparency reformers who vainly seek a singular discursive and administrative register. Pluralistic land ownership patterns across much of colonial urban Africa thus result from the overlapping rent-seeking strategies of chiefs, lineages, state authorities (often multiple), and speculative investors. ${ }^{35}$ In Taifa, I examine the formative role of urban rents, as well as the strategy of rent-seeking and the formation of a landlord strategy in shaping the physical structure and political debates of colonial and early postcolonial Dar es Salaam. The most diffuse and accessible strategy of capital accumulation in cities such as Dar es Salaam has been and continues to be the accumulation of rents. Dar es Salaam's high rents for rooms and houses were not only indicators of urban immiseration for those on the economic margins, though that cannot be denied; they were also powerful evidence of successful strategies of capital accumulation by landlords of varying means and all colors. The work of landlords who set out to capture these expensive rents did considerably more to determine the physical shape of colonial and particularly postcolonial urban growth than did the works of colonial urban planners. The built environment of Dar es Salaam's older neighborhoods like Kariakoo, Ilala, and Magomeni, and in particular that of its more recent and more distant neighborhoods such as Tabata, Segerea, Ubungo, and Mbagala, cannot be remotely understood with reference to urban plans and regulations alone. Whether or not landlords are most profitably understood as a class, or as a coherent strategy, their role in shaping Africa's physical and economic landscape - which

T. C. McCaskie, Asante Identities: History and Modernity in an African Village 1850-1950 (Bloomington IN: Indiana University Press, 2000), 215.

34 Berry, xxii.

35 For an excellent overview of urban property markets in Africa, see Carole Rakodi, 'Residential property markets in African cities', in Carole Rakodi (ed.), The Urban Challenge in Africa: Growth and Management of its Large Cities (Tokyo: The United Nations University Press, I997), 37I-4Io. 
are far too often credited to urban planners - remains the most fundamental lacuna in the study of African cities generally. My story is one about rent-seeking, and this also means attending to the historical role of the original 'rent-seekers', the urban 'first-comers' - in Dar es Salaam, this meant the ethnic Zaramo and Shomvi - whose social, legal, and spiritual claims over the city similarly shaped the environment of colonial and postcolonial urban growth..$^{36}$ The most neglected element of how these 'first-comers' shape urban environments is the role played by the 'invisible' actors in shaping the urban landscape of the living. Largely invisible to colonial and postcolonial legal regimes, spiritual land markers such as graveyards, grave sites, and spirit shrines were principal points of local orientation among Shomvi and their tenants in Dar es Salaam. Land rents are thus importantly necropolitan phenomena. In poorly titled and surveyed areas, rent payments were the most reliable indicators of successful land claims, and Shomvi often collected ubani land rent. Literally meaning 'incense', ubani was commonly used in Muslim prayers as well as mizimu (spirits) propitiations carried out through the intercession of long-term residents. Shomvi in the Iggos collected ubani in the form of gifts or payment, the payer knowing that it would not be used to purchase incense, but instead serve as the newcomer's sacrament to a successful first-comer claim. ${ }^{37}$ Its origins lay in an earlier time when the significance of land rents was more symbolic and tributary than financial. Such spiritual land markers remain an important reference point in court cases and social mental geographies across the continent. Indeed, it is at points where the dead no longer anchor claims of the living, when death occurs outside of any viable kinship network, as De Boeck and Plissart observe in Kinshasa, that death has 'therefore lost its capacity for implacement', and therefore marks a serious and fundamental transformation in Africa's urban cityscapes.$^{3}$ From the grave guardian to the international property speculator, the principle of rent generation through exploiting land scarcity with legal-historical claims has created and sustained Africa's most consequential urban group, the landlord.

Finally, let us return to another debate from the era of normative approaches, the question of rural development. The most influential liberal criticism of African's rural production problems of the I970s and I980s was made by Robert Bates, who argued that postcolonial Africa was cursed with an urban bias in its economic policies - the unfair pricing of goods and services that flow between rural and urban areas. ${ }^{39}$ In my own work, I locate the origin of this set of policies for Tanzanian in the wartime urban colonial state of the I940s, which was a regulatory state that extended basic minimum guarantees of food and clothing in return for visible full employment. Urban space grew within this regulatory texture of price and mobility controls, with several long-ranging effects, including what development economists would come to term 'urban bias'. Around I939,

\footnotetext{
36 See Brennan, Taifa, especially chapter 2.

37 See especially Geoffrey Ross Owens, 'The Shomvi: A Precursor to Global Ethnoscapes and Indigenization in Precolonial East Africa', Ethnohistory 53 (2006), 730-73I.

38 De Boeck and Plissart, Kinshasa, $\mathbf{3} 3$.

39 The classic statement of this view is Michael Lipton, Why Poor People Stay Poor: A Study of Urban Bias in World Development (London: Temple Smith, I977).
} 
Dar es Salaam's rate of population growth leaped from its inter-war pace of two percent to around eight percent, which would remain so for decades after independence in $196 \mathrm{I}$. The state responded by creating what I have termed 'urban entitlement', a set of spatially-defined legal rights to minimum necessities through the state regulation of market transactions, represented by the creation of a new bundle of spatially defined entitlements for legal urban residents - universal food and clothing rations, rent controls, and employment-based government housing. ${ }^{4^{\circ}}$ In particular, by guaranteeing food access, the colonial government's rationing scheme of 1943 gave immediate material meaning to urban space. Both before and after the war, there was never a neat separation between rural and urban - rural ties were retained by most residents of Dar es Salaam for reasons to do with security, welfare, affective relations, and opportunities in petty trade and in agriculture. What changed was the universal and abstract nature of entitlement, symbolized in official prices and ration coupons, and effectively mediated through identity categories of race, rather than through interpersonal relations of patronage that had loomed large in the decades before the Second World War. Although controlled prices were not cheap and quality was often abysmal, comprehensive rationing entrenched a basic level of urban food security that had no rural counterpart. And this was certainly not limited to urban East Africa. Ayodeji Olukoju has shown that wartime Lagos was similarly a city overwhelmed by scarcity and inflation, in which rations and other regulations were attempts to secure urban political security in the face of unrest against dreadful living conditions and merchant and landlord profiteering. ${ }^{4}$

Postcolonial policies continued to effectively subsidize urban living through the regulatory framework that constitutes urban entitlement..$^{22}$ Tanzania in this sense represented a textbook case of 'urban bias', in which currency overvaluation and low commodity pricing raised urban living standards, encouraged urban migration, and discouraged export-oriented rural production. In other words, urban entitlement - those regulations established during the war that effectively subsidized, however modestly, food and other commodities not similarly guaranteed in rural areas - continued to be part of what attracted urban immigrants to Dar es Salaam and other cities across much of Africa after independence. Yet in terms of specific urban policies and stated national goals, Tanzania paradoxically represents one of Africa's most anti-urban postcolonial states. Ujamaa rhetoric and policy alike stressed that the nation's primary activity was agriculture and implied that cities themselves, particularly Dar es Salaam, were parasites benefitting from the larger nation's agricultural sweat. What had changed was not ultimately 'pro-urban' policies, but instead the quite public and performative nature of what it now meant to be a productive urban denizen. In the ig6os and I970s, one had to be seen performing the tasks of a citizen (in Swahili, mwananchi) in front of one's fellow nationalists, namely by combating exploitation (in Swahili, unyonyaji), particularly when the nation's rural

\footnotetext{
40 Brennan, Taifa, chapter 3. What follows comes from this chapter.

4I Ayodeji Olukoju, 'The Cost of Living in Lagos I9I4-45', in David M. Anderson and Richard Rathbone (eds.), Africa's Urban Past (Oxford: James Currey, 2000), I34-I40. 
work was being left undone. National citizenship ideals in postcolonial Tanzania concerned public performance at least as much as they did legal status. Because cities were primarily sites of consumption that generated unwholesome divisions of labor, the ideal urban citizen was also someone who held urban life in contempt. A sharp anti-urban populism thrived in Dar es Salaam amid mass urban migration, juxtaposing associations of rural African virtue with urban non-African indulgence. Urban nodes of racial density embodied in the image of Indians closely clustered in commercial shops and high-rise residences should yield to an Africanized landscape of evenly distributed, low-density ujamaa villages.

Urban entitlement marks an important material basis for life in East Africa, and no doubt farther afield. African city life, even in places where the state is quite weak, is nonetheless a site of far greater potential challenge to political authority over Africa's twentieth century than have been its rural areas. ${ }^{43}$ The policy legacy of this challenge remains one of regulatory placation of urban space, in which food, clothing, and (in certain cases for key actors) housing have been largely more affordable and more accessible, even as anti-urban sensibilities continue their work of self-flagellation long after independence.

\section{Conclusion}

Since the I990s, Africanist academics have largely abandoned employing normative frameworks to understand the constantly transforming environments of African cities. Modernization theory is well and truly dead as an Africanist method and theory, if not as a historical concern, or theoretical orientation of other contemporary actors. Similarly, Marxist approaches, even the most subtle and powerful framings demonstrated in the earlier work of Frederick Cooper, receive admiration but not employment. Instead, the current literature is dominated by the broad claims of anti-liberalization critics on the one hand, for whom Africa is largely interchangeable with other regions of the world's urban immiseration sites, like South Asia and Latin America. On the other hand looms the far richer but also far more idiosyncratic work of urban ethnographers, most prominently AbdouMaliq Simone. This latter work has highlighted the unformed and subjective nature that characterizes so much of urban life, not just in Africa but everywhere. There is no question that we no longer have good reason to expect uni-linear modernity to shape African cities, as Simone and others have decidedly demonstrated. Yet by eschewing normative thought, Africanists have also eschewed comparative models and suggestive typologies that allow for comparison between cities in order to make generalizations that may or may not hold within regions of Africa, or within Africa more broadly. There are realities that importantly connect people within cities, and cities with countrysides, and cities with other cities, which are firmly objective and material, shaped by the legacies of colonial and early postcolonial policies, patterns of urban rent gathering, and broad trends in urban-bound movements. In particular, natural and invented forms of scarcity - from urban housing, to quality education and health care, to space for commu- 
ting and transportation - are primed to sharpen and shape future urban desires, inspire new and ever-more creative strategies of rent-seeking, and form the basis for the urban shapes of Africa's future. For the African city yet to come is one that is already here, and one that draws upon the material strategies and claims long pioneered by landlords, renters, consumers and middlemen since the last century and before. 